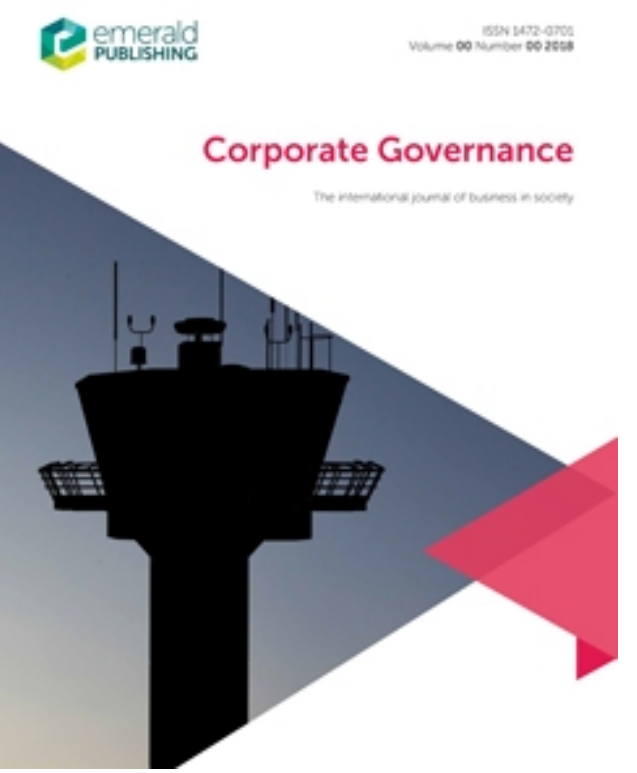

\title{
THE ROLE OF CORPORATE GOVERNANCE ON CSR DISCLOSURE AND FIRM PERFORMANCE IN A VOLUNTARY ENVIRONMENT
}

\begin{tabular}{|r|l|}
\hline Journal: & Corporate Governance \\
\hline Manuscript ID & CG-06-2019-0184.R2 \\
\hline Manuscript Type: & Original Article \\
\hline Keywords: & $\begin{array}{l}\text { Corporate Governance, Board Size, Board Independence, Nigeria, CSR } \\
\text { Disclosure }\end{array}$ \\
\hline \multicolumn{2}{|l}{} \\
\hline
\end{tabular}

\section{SCHOLARONE \\ Manuscripts}




\title{
THE ROLE OF CORPORATE GOVERNANCE ON CSR DISCLOSURE AND FIRM PERFORMANCE IN A VOLUNTARY ENVIRONMENT
}

\begin{abstract}
Purpose: This study investigates the impact of corporate social responsibility disclosure (CSRD) on firm performance and the moderating role of corporate governance on the CSRDfirm performance relationship of listed companies in Nigeria.

Design/methodology/approach: The paper uses a panel dataset comprised of 841 firm-year observations for the period covering 2007-2016. Fixed effect regression analysis was used to examine the relationship between CSRD and firm performance, and the moderating role of corporate governance in the CSRD-firm performance relationship.

Findings: The results of the study show that there are positive performance implications for firms that engage in CSRD. Although we find no effect of board size on the CSRD-firm performance relationship, we provide strong evidence of a positive effect of board independence on the CSR-firm performance relationship.

Theoretical and Practical Implications: The study contributes to the understanding of CSRD-firm performance relationship by providing evidence of the moderating role of corporate governance. It is, therefore, recommended that a stronger regulation be put in place for CSR engagement and the disclosure of same in Nigeria as well as robust measures for the enforcement of corporate governance mechanisms as there are economic benefits to be derived.

Originality/value: The findings contribute to the literature by providing up-to-date and original insights on the CSRD-firm performance link within a developing country context. It also employs an uncommon method of measuring CSRD, taking into account the institutional biases that may arise from other methods employed in studies on developed countries.
\end{abstract}

Keywords Corporate governance, CSR disclosure, board size, board independence, firm performance, Nigeria. 


\section{Introduction}

Corporate social responsibility (CSR) continues to be an issue of interest to a diverse range of stakeholder groupings. This is largely because it is the primary means of ascertaining the extent of an organisation's contribution to the welfare of its environment. Consequently, interest in CSR has grown in the literature as firms continue to consider means of simultaneously pursuing economic profits and contributing to societal well-being (Oh, Hong, and Hwang, 2017). One way of being accountable to society and stakeholders is for organisations to engage in CSR practices and disclose the outcome of those practices. Corporate social responsibility disclosure (CSRD) entails communicating CSR outcomes which helps to legitimise organisations' activities.

An organisation's profitability, as well as its existence, could be affected by its form and extent of CSRD which can be driven by the governance structure in place. Corporate governance is premised on the need to reduce the dichotomy and asymmetry that exist between the principal (shareholders) and agents (management) in an organisational setting. Due to the principal-agent conflict posed by the separation of ownership from control, agency theory was introduced by Jensen and Meckling (1976) as a lens through which corporate governance can be viewed. This theory suggests that agents, as individuals, can be self-interested and opportunistic (Aguilera, 2005) and less likely to protect the principals as owners in terms of their interests, but rather pursue their personal gains, including risk avoidance, financial manipulation for compensation, optimization and embezzlement of corporate resources (Dey, 2008).

CSR can be utilised as a tool by managers to foster their personal interests which might negate those of the shareholders. The strength of the corporate governance mechanisms in place would serve to either forestall or encourage the achievement of managers' individualistic interests in the utilisation of CSR decisions. This, therefore, portrays that the financial outcome (profitability) of CSR activities and their attendant disclosures could be affected by the nature 
and effectiveness of the corporate governance mechanisms that exist in the organisation. Therefore, in aiding a concise understanding of the relationship that exists between CSRD and financial performance, it becomes expedient to analyse the moderating effect of corporate governance on the aforementioned relationship.

In Nigeria, CSRD in annual reports is not a mandatory process, hence acting in a socially responsible manner is not necessarily guaranteed. Despite this voluntary regime, it has been observed that some listed companies in Nigeria have decided to engage in CSR activities and disclose this in their annual report. It is therefore imperative to examine the effect, if any, of CSRD on the performance of companies in Nigeria. In addition to the voluntary system, Nigeria, like most developing countries, is plagued with weak institutions, poor governance practices, weak enforcement agencies and corrupt practices (Adegbite, 2015, Amaeshi et al., 2016; Chijoke-Mgbame and Mgbame, 2018). These shortcomings in the system no doubt provide an enabling environment for firms not to engage in CSR activities and also not to disclose the same in any format. Nonetheless, some companies have decided not to capitalize on the loopholes in the system, but have gone ahead to engage and disclose their CSR activities, given that there may be financial consequences. This, therefore, provides the motivation for the current study. The first objective is to examine the economic impact of CSRD on the performance of companies in Nigeria. The second objective is to empirically provide evidence of the role of corporate governance on the CSRD-performance relationship. We examine corporate governance, as the decision to engage in CSR-related activities lies with the management, of which the board is a part. To the best of our knowledge, no study in Nigeria has examined the combined effect of corporate governance and CSRD on firm performance. We add to the current research on CSR in the following ways. Firstly, we provide empirical evidence on the effect of CSRD on firm performance in a developing country context, with a focus on Nigeria where there are relatively few studies. Given that Nigeria is one of the largest 
countries in Africa, the findings of this research serve as a building block for further scholarship in the region. Secondly, we go beyond other CSR-performance studies, to provide evidence on the moderating role of corporate governance on the relationship between CSRD and firm performance. Specifically, we examine the size and independence of the board, as Bebchuk and Fried (2004) note that they are direct outcomes of a firm's governance process. Thirdly, we employ a different approach in the way we measure CSRD. Specifically, we examine the annual report using content analysis to see if there is a dedicated section for CSR. Companies in Nigeria are not under any obligation to report on their CSR activities in the annual report. For companies to dedicate a section of the annual report to CSR, it, shows that such activities are of great importance to the reporting entity.

The rest of the paper is organized as follows: Section 2 provides the theoretical background. Section 3 provides a review of the literature and develops the hypotheses. The penultimate section discusses the research methods, data analyses and results, while the last section concludes the study.

\section{Theoretical Background}

\section{Corporate Social Responsibility}

In the past, businesses have traditionally been seen as economic actors (profit driven) and government as political actors encumbered with the responsibility of societal development (Sundaram and Inkpen, 2004). Early attempts on the study of CSR have defined the concept as obligations of businesses to "pursue those policies, to make those decisions, or to follow those lines of action which are desirable in terms of the objectives and values of our society" (Bowen, 1953, p6). However, the dramatic increase in globalization and international trade across the world has seen new demands for improved transparency and corporate citizenship that aligns the process and outcomes of businesses to the needs and expectations of society. This has led to a range of concepts that can be linked to CSR, including corporate social 
performance (Wartick and Cochran 1985) and corporate social responsiveness (Sethi, 1979). These notions create a level of varying definitions with various perspectives ${ }^{1}$ that seek to align the economic and social orientation of businesses as important actors in firm performance. That notwithstanding, CSR has been described as "an ill and incompletely defined concept" (Baron, 2010, p9), making it prone to a number of conflicting interpretations (Amaeshi and Adi, 2007). Notwithstanding the lack of consensus on the definitions of CSR (McWilliams et al., 2006), a common trend in the various definitions is the notion of responsible and sustainable corporate behaviour that facilitates a firm's long-term interest.

In a bid to understand the rationale and strategies for CSR engagement, a number of theories have emerged. For instance, the stakeholder theory (Freeman, 1984) postulates that the objectives of a firm should go beyond maximizing the wealth of shareholders and incorporate the needs of its numerous stakeholders, such as employees, customers, community and suppliers. This argument is also premised on the broader conception of corporate governance, which suggests, “companies and societies are interdependent” (Kiel and Nicholson, 2003, p31). Another important theoretical explanation of CSR is legitimacy theory (Gray et al., 1995; Deegan, 2002) which stems from the notion of a social contract that exists between the business organisation and the society in which it operates. To survive and progress in society, business organisations must, therefore, fulfil their part of the contract by taking into consideration the values and norms of society. Organisations therefore engage in CSR activities in order to legitimise their behaviours and actions. One way for firms to legitimise their actions is through the disclosure of their CSR activities in their annual reports. The resource dependency theory (Pfeffer and Salancik, 1978) has also been used to explain the notion of CSR. This theory argues that it is the amount of resources available to the organisation that determines the extent of its CSR activities. These resources could be tangible or intangible, financial and non-

\footnotetext{
${ }^{1}$ See Idowu and Papasolomou (2007) for various definitions of CSR
} 
financial, internal or external. Institutional theory (Campbell, 2007), on the other hand, argues that the institutional environment of the organisations determines their CSR. These could be the regulations provided by private and public bodies, the existence of non-governmental agencies and the monitoring role they perform, the institutionalised norms of society and the behaviour of other organisations within the industry or sector.

\section{Corporate Governance}

The concept of corporate governance is based on the underlying principle of separation of ownership and management, as first identified by Berle and Means (1932). In order to minimize the potential conflict of interest that may arise as a result of the separation of ownership and control, the agency theory (Jensen and Meckling, 1976) proposes corporate governance as a means to address the principal-agent conflict. Proponents of corporate governance mainly fall into two categories - those who consider corporate governance as a tool to protect shareholder/owner interests (the narrow perspective), and those who consider it within the wider spectrum of protecting stakeholder interests (the broader perspective). While proponents of the broader perspective of corporate governance may have been policymakers or advocates, proponents of the narrow perspective are advocates of agency theory in favor of shareholders wealth maximization. There are however, limits to which the agency theory can be applied (Kolk and Pinske, 2010). That notwithstanding, the broader perspective of corporate governance has evolved to include the relationship between companies and a wider range of stakeholders, such as shareholders, employees, creditors, suppliers, communities and customers, as being equally significant investors (Jamali et al., 2008; Monks and Minow, 2004). These stakeholders provide the resources that contribute to the firm's survival, success and competitiveness. The narrow perspective, on the other hand, considers the return on investment to suppliers of finance as the major focus of the firm with very minimal consideration of social and environmental activities (Saravanamuthu, 2004). 
Regardless of the narrow (shareholder) or broader (stakeholder) perspective, the impact of corporate governance on firm performance (financial and non-financial) cannot be overemphasized. The board of directors and the role boards play as major actors in corporate governance have attracted considerable attention in recent times (Darko et al., 2016). This has also led to the emergence of various theories of corporate governance to strengthen debates on the link between the board of directors and firm performance. The agency theory situates the role of the board as a custodian charged with the day-to-day management of the company on behalf of shareholders. One key mechanism relevant to this theory is board independence as a monitoring tool to control management actions (Tricker, 1994). Over time, the agency theory has led to a number of controversies, leading to the development of new theories; for instance, stewardship theory, which is based on the premise that managers are predominantly trustworthy and essentially reliable custodians of resources given to them, in which monitoring and independence are irrelevant (Donaldson and Davis, 1991). The resource dependence theory, as noted by Pfeffer and Salancik (1978), considers that firms are dependent on external constituents as a means of procuring and transacting with necessary resources in order to survive. The board of directors is therefore viewed as the unit through which crucial resources such as legitimacy and counsel are linked to the firm (Hillman and Dalziel, 2003). Finally, stakeholder theory goes a step further in emphasizing the role of boards beyond shareholder protection and management monitoring to include wider social responsibilities of stakeholder accountability, corporate citizenship and societal stewardship in forms such as reporting and disclosure (Keasey and Wright, 1997). As noted by Kiel and Nicholson (2003, p31) "the board of directors should be able to judge whether the interests of all stakeholders are being justly balanced". The various theories discussed above suggest a relationship between the board of directors, as active participants in corporate governance with the potential to influence CSRD and overall firm performance. 


\section{Literature review and hypotheses development}

The above theoretical exposition has laid the foundation for numerous studies on the effect of the two concepts (corporate governance and CSRD) on firm outcomes, such as firm risk (Jo and $\mathrm{Na}, 2012$ ), earnings management (Kim et al., 2012), reputation (Lev et al., 2010), profitability (Mishra and Suar, 2010), amongst others. The majority of these studies, however, focus on either of the two concepts with few examining the joint effect of corporate governance and CSRD on firm performance. In addition, most of the prior studies focus on developed economies with a strong institutional framework and effective governance systems. For example, in the UK, Qiu et al., (2016) find that there is increased market value for firms with higher social disclosures. When compared with environmental disclosure, they conclude that social disclosure is more important to stakeholders of the firm. Servaes and Tamayo (2013) find a positive relationship between CSR and firm performance for a sample of US firms. Moreover, the relationship is mediated by consumer awareness. Specifically, they find that for firms with low customer awareness, there is a negative or insignificant relationship between CSR and performance. From a transitional economy perspective, Wang et al. (2015) show that, using a quantile regression analysis for a sample of Taiwanese firms, the positive relationship between CSR and firm performance is driven by brand equity. Further analysis reveals that this positive relationship is driven by brand equity. In contrast, they find that brand loyalty negatively impacts on the relationship between CSR and firm performance. Relatedly, Mishra and Suar (2010) find that for Indian firms, there is a positive relationship between CSR and firm performance across different dimensions of CSR activities.

A review of prior empirical studies reveals contradicting viewpoints on the relationship between corporate governance mechanisms and firm performance, with divergent results. For instance, Cheng (2008) provides evidence of a negative relationship between board size and the performance volatility of firms in the US. They argue that as board size increases, firms are 
less likely to take extreme decisions which, in turn, leads to lower variation in corporate performance. Similarly, Ujunwa (2012), Guest (2009) and Lasfer (2004) find a negative relationship between board size and firm performance measured by return on asset employed, Tobin's q and stock returns for UK companies. From the banking industry, Liang et al., (2013) find that board size reveals a negative association with firm performance in China. Using board size as a control variable, Bennouri et al., (2018) find that there is a negative effect of board size on Tobin's q. On the contrary, some studies provide evidence that board size positively affects firm performance (see Belkhir, 2009; Bhagat and Black, 2002; Guest, 2009), while others find no effect of board size on firm performance (Assenga et al., 2018; Duru et al., 2016). The independence of the board is another governance mechanism that is strongly debated in the literature. The argument shows that independent directors serve as better monitors of the firm on behalf of shareholders (Adams et al., 2010). Independent directors have also been found to be a source of additional resources for the firm (Duppati et al., 2019). While some studies show there is a positive relationship between board independence and firm performance, others provide a negative or insignificant relationship. For instance, O’Connell and Cramer (2010) find a strong positive association between board independence and firm performance for Irish firms. Joh and Jung (2012) find that board independence positively affects firm value in a sample of Korean firms; however, they document that this positive relationship exists when there are low information transaction costs. Duppati et al. (2019) conclude that there is a positive relationship between board independence and firm performance in Spanish firms. Similarly, Liu et al., (2015) show that there is a positive relationship between board independence and firm operating performance for Chinese firms. The positive effect is stronger for government-controlled firms. Similar positive findings have been documented in early studies for the UK (Ezammel and Watson, 1993) and the US (Pearce and Zahra, 1991). In contrast, Erkens et al., (2012) document a negative effect of independent directors on firm 
performance for Bank Holding Companies in a cross-country analysis, whereas, Adams and Mehran (2012) find no relationship between board independence and firm performance. From the family business perspective, García-Ramos and García-Olalla (2011) reveal a negative effect of board independence on performance when the descendants of the founder are in charge of running the firm, but for the founder-controlled firm, they find a positive effect of board independence on performance.

In light of the foregoing, there are obvious conflicting results on the relationship between CSR and firm performance on the one hand, and corporate governance and firm performance on the other. The decision to engage in CSR activities is one strategic decision made by the board. Our argument is that given the weak governance system in Nigeria, firm-specific corporate governance practices may play a moderating role in the CSR-firm performance relationship. We, therefore, propose the following hypotheses;

H1: There is a positive relationship between CSR and firm performance

H2: Board size positively affects the relationship between CSR and firm performance

H3: Board independence positively affects the relationship between CSR and firm performance

\section{Data, methodology and model specification}

The population of the study consists of listed companies on the Nigerian Stock Exchange, with the exclusion of financial firms due to a more regulatory requirement for financial firms. We also deleted firms without relevant information for analysing the hypothesized relationships. The final sample is an unbalanced panel data which is made up of 83 companies with 841 firmyear observations for the period covering 2007-2016.

The dependent variable for our study is return on asset (ROA) this is measured as earnings before interest, taxes, depreciation, and amortization (EBITDA) divided by total assets. The advantage of using EBITDA rather than net income is that it allows for comparison across forms. Following Chijoke-Mgbame and Mgbame (2018), the independent variable CSRD is 
measured as a dummy variable taking the value of 1 if there is a section in the published annual report dedicated to CSR activities and 0 otherwise. Given the voluntary disclosure system in Nigeria, companies that decide to dedicate a section in their annual report to discuss and present their CSR activities demonstrate the importance of such activities to the company. To obtain this information, the annual reports for each company were downloaded from the respective companies' websites in order to determine if there is a section dedicated to the disclosure of CSR activities of the company or not.

Next, we collected data for our two measures of corporate governance which are used as the interaction variables; board size and board independence. Board size is measured as the number of directors on the board; board independence is measured as the percentage of independent directors on the board. We collected the data from both Bloomberg and the annual reports. For those without information on Bloomberg, we hand collected the information from the annual report; the same applies to the control variables. To minimize the effects of outliers, all variables except the dummy variables were winsorized. We specify the model in line with the hypotheses:

$R O A$

$$
\begin{aligned}
& =\beta_{0}+\beta_{1} \text { CSRD }_{i t-1}+\beta_{2} \text { BSize }_{i t-1}+\beta_{3} \text { BInd }_{i t-1}+\beta_{4} \\
& \text { Control Variables } \\
& i t-1
\end{aligned}
$$

ROA

$$
\begin{aligned}
& =\beta_{0}+\beta_{1} \operatorname{CSRD}_{i t-1}+\beta_{2} \text { BSize } * \operatorname{CSRD}_{i t-1}+\beta_{3} \text { BSize }_{i t-1}+\beta_{4} \\
& \text { Control Variables } \text { S }-1_{i t}+\mu \ldots(2)
\end{aligned}
$$

ROA

$$
\begin{aligned}
& =\beta_{0}+\beta_{1} \operatorname{CSRD}_{i t-1}+\beta_{2} \operatorname{BInd} * \operatorname{CSRD}_{i t-1}+\beta_{3} \operatorname{BInd}_{i t-1}+\beta_{4} \\
& \text { Control Variables } \text { Vit }-1_{1}+\mu \ldots \text {...(3) }
\end{aligned}
$$

\section{Presentation and analysis of data}


Table 2 presents the descriptive statistics of the variables. We observe that the mean for the CSRD is 0.44 which indicates that $44 \%$ (less than half) of the sampled firms have a dedicated section for CSRD. The standard deviation of 0.5 indicates the degree to which CSRD for the sample exhibits significant clustering around the mean. ROA, the performance measure, has a mean of 2.74 with a standard deviation of 17.05 . The average board size in the sample is 8.91 , with a minimum of 4 and a maximum of 19. The level of board independence in the sample is between 16.67 and 88.89 with an average of 62.38 . This shows that more than half of the sampled firms have an independent board. The mean age of the sampled firms is 24.58 with a minimum of one year and a maximum of 56 years. The statistics on leverage reveal a mean of 76.77 , with an approximate standard deviation of 140 . This suggests that there is a huge variation in the level of debt amongst the sampled firm. This supports the use of EBITDA as a more appropriate measure of firm performance. Table 2 also shows the results of the test for multicollinearity in the last column (VIF). The presence of multicollinearity could lead to unreliable coefficient estimates. We conduct the VIF (Variance Inflation Factor) test to check for this problem. Landau and Everitt (2004) suggest that a VIF value of 10 and above is a cause for concern. The results reveal that there is no multicollinearity problem as all VIF values are below $10^{2}$.

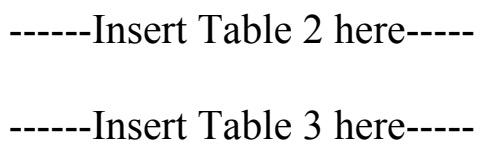

The nature of the data used for this study suggests that there may a problem of causality between the dependent and independent variables. Also, there may be some time-invariant

\footnotetext{
${ }^{2} \mathrm{We}$ also check for high correlations among the variables. But the correlation results reveal that there is no cause for concern. We do not report the results due to word count limits.
} 
firm-specific characteristics in the data. Therefore, the use of ordinary least squares will not be appropriate for this study. To proceed, we conduct the Hausman test to decide between the use of a fixed effect or a random effect model; the Hausman test supports the use of a fixed effect estimation.

Table 3 presents the results of four regression analyses ${ }^{3}$ using the fixed effect model. Model 1 shows the effect of CSR disclosure on firm performance. We find that there is a statistically positive relationship $(\beta=0.236, \mathrm{p} \leq 5 \%)$ between CSRD and firm performance. This provides support for hypothesis 1, that, for Nigerian companies, engaging in CSR disclosure positively affects firm performance. One possible reason for the positive result is that firms which engage in CSR-related activities are likely to have a good reputation and also attract the attention of consumers in society which can positively affect firms' financial performance. The results are in tandem with prior studies, such as Saeidi et al. (2015), which find that CSR positively affects firm performance through reputation and customer satisfaction amongst Iranian firms. Similarly, Madueño et al., (2016) show that there is a positive relationship between CSR and firm performance for Spanish SMEs (see also, Qiu et al., 2016; Servaes and Tamayo, 2013). Next, in Model 2 of Table 3, we include an interaction variable to capture the mediating role of corporate governance (board size) on the relationship between CSRD and firm performance. The coefficient of the interaction variable, although positive, is not statistically significant. Thus, we fail to accept hypothesis 2 . The results suggest that the size of the board does not affect the relationship between CSRD and firm performance. Prior studies (Assenga et al., 2018; Duru et al., 2016) find no evidence of a relationship between board size and firm performance. In Model 3 of Table 3, we include an interaction variable CSRD*BInd. This is to capture the moderating effect of independent boards on the relationship between CSRD and firm performance. We find that there is a statistically positive relationship between the

\footnotetext{
${ }^{3}$ For brevity we have included all regressions in one table.
} 
interaction term $\left(\mathrm{CSRD}^{*} \mathrm{BInd} ; \beta=0.014, \mathrm{p} \leq 5 \%\right)$ and firm performance. This result suggests that having independent directors on the board enhances the CSRD, which increases the financial performance of the company. Thus, providing support for hypothesis 3 . The results also support advocacy for more independent boards as independent directors serve as useful resources for the firm, especially for countries with weak institutions and poor governance. Furthermore, prior studies find that there is a positive relationship between board independence and CSR. For example, Lone et al., (2016) provide evidence of a positive relationship between board independence and CSR disclosure for selected firms in Pakistan. Also, Ducassy and Montandrau (2015) find a positive association between CSR and firm performance in France, while Malik and Makhdoom (2016) and Liu et al., (2015) provide a positive association between board independence and firm performance.

In addition to the main variables, we have included a number of control variables. In model 1, we include both corporate governance variables. However, we include one of the governance variables at a time in models 2 and 3 respectively to avoid capturing the effect of the other governance variables in the interaction models. In model 1, we find a statistically positive relationship between board size and firm performance. This is in support of prior studies, which find that large boards are advantageous to firms. Large boards tend to bring various ideas and opinions, which could improve the quality of decision-making. However, a few studies (see, Bennouri et al., 2018; Guest, 2009) have found a negative effect of large boards on firm performance, citing long decision-making processes and the potential for 'group think' which can result in poor firm performance. In model 1, we also include board independence as a control variable. We find a statistically positive effect of board independence on firm performance; this suggests that more independent boards increase firm performance. The results are consistent with Liu et al., (2015) who find a positive effect of board independence on firm performance. To control for firm specific factors, we include a host of control variables 
in all models. We do not find a significant relationship between firm size and ownership structure in all models. We find a marginally significant positive effect of firm age on performance in Model 2. In all models, we find a statistically significant relationship between firm cash and big4auditors on firm performance, thus suggesting that cash availability increases firm performance and that the use of one of the big 4 audit companies positively affects firm performance. For leverage, we find a statistically negative relationship with firm performance. This result suggests that debt reduces firm performance, as observed in Singh and Faircloth (2005) and Assenga et al., (2018). Lastly, ownership structure, although negative, exhibits no statistical effect on firm performance, (see, Demsetz and Villalonga, 2001). As a robustness check, we include both interaction variables and control variables in Model 4; we find that the results remain the same.

\section{Conclusion}

This paper attempts to contribute to the broader literature of CSRD by examining the nexus between CSRD and firm performance. Drawing on the legitimacy and stakeholder theories, we extend this line of inquiry by moderating the corporate governance factor on the perceived relationship within a voluntary environment. Whilst most studies focus on the direct relationship between CSRD and firm performance, we ventured to provide evidence as to how corporate governance could influence the aforementioned relationship. Consequently, the study adopted a novel approach by confirming the perceived relationship and showing how specific corporate governance mechanisms affect the relationship.

Although companies have been credited with engaging in CSR, they have also been criticized for either no, or inadequate, disclosures of their activities. Despite the fact that some countries are promoting mandatory disclosure, while others operate a voluntary regime, CSRD has increased universally in both complexity and dimension over the past two decades. In most developing countries such as Nigeria, CSRD still relies on the voluntary initiatives of the 
reporting entity. Undoubtedly, in the absence of any mandatory requirement, with the weakness of institutions and paucity of laws, companies operating in this kind of environment are likely to take advantage of the poor governance system to de-emphasize disclosure. It is against this backdrop that we consider the imperativeness of examining the financial performance consequences of firms that have decided to look beyond the weaknesses in the system to do what is right.

The results of the study show that there are positive performance implications for firms that engage in CSRD. Notwithstanding the poor governance system, some firms in Nigeria still adhere to the statutory governance mechanisms of appropriate board size and board independence. Since the board is involved in steering the strategic direction of the firm, we investigate the effect of these two governance tools on the relationship between CSRD and firm performance. Although we find a direct effect of board size on firm performance, we do not find any significant moderating effect of board size on the CSRD-firm performance relationship. However, we provide strong evidence of a positive effect of board independence on the CSRD-firm performance relationship.

This study, therefore, recommends stronger legislation and regulation for CSR engagement and disclosure amongst Nigerian companies as there are economic benefits to be derived whilst addressing the needs and improving the lot of society. In addition, the corporate governance systems in Nigeria should be rebranded and made stronger with the formulation of relevant policies that can promote implementation and enforcement. This is important as this study has shown that the governance system can improve the associated effect of CSR on firm performance. For instance, this study provides evidence to support the fact that the promotion of independent boards can improve firm performance.

We acknowledge there are some limitations of our study but these provide interesting avenues for future studies. Although our study spans a number of years and firms, some governance 
mechanisms were not tested due to unavailability of data. In addition, we only consider listed firms; therefore, an examination of private firms may add to the findings. The unavailability of authentic data also prevented the inclusion of such firms. Nevertheless, the aforementioned limitations do not affect the validity of the results obtained. 


\section{References}

Adams, R., Hermalin, B. E., and Weisbach, M. S. (2010). "The role of boards of directors in corporate governance: A conceptual framework and survey", Journal of Economic Literature, Vol. 48, pp 58-107.

Adams, R. B. and Mehran, H. (2012), "Bank board structure and performance: Evidence for large bank holding companies", Journal of Financial Intermediation, Vol. 21 No. 2, pp. 243267.

Adegbite, E. (2015), "Good corporate governance in Nigeria: Antecedents, propositions and peculiarities”, International Business Review, Vol. 24 No. 2, pp. 319-330.

Aguilera, R. V. (2005), "Corporate governance and director accountability: An institutional comparative perspective", British Journal of Management, Vol. 16, S39-S53.

Amaeshi, K. M., Adegbite, E. and Rajwani, T. (2016), "Corporate social responsibility in challenging and non-enabling institutional contexts: Do institutional voids matter?", Journal of Business Ethics, Vol. 134 No. 1, pp.135-153.

Amaeshi, K. M., and Adi, B. (2007), "Reconstructing the corporate social responsibility construct in Utlish", Business Ethics: A European Review, Vol.16 No. 1, pp. 3-18.

Assenga, M. P., Aly, D., and Hussainey, K. (2018), "The impact of board characteristics on the financial performance of Tanzanian firms", Corporate Governance: The International Journal of Business in Society, Vol. 18 No. 6, pp. 1089-1106.

Baron, D. (2010), Business and its environment (6 ${ }^{\text {th }}$ ed.), Pearson Prentice Hall, Upper Saddle, New Jersey.

Bebchuk, L. A., and Fried, J. M. (2003). Executive compensation as an agency problem. Journal of Economic Perspectives, Vol. 17 No. 3, pp. 71-92.

Belkhir, M. (2009), "Board of directors' size and performance in the banking industry", International Journal of Managerial Finance, Vol. 5 No. 2, pp. 201-221.

Bennouri, M., Chtioui, T., Nagati, H., and Nekhili, M. (2018), "Female board directorship and firm performance: What really matters?” Journal of Banking \& Finance, Vol. 88, pp. 267-291.

Berle, A. and Means, G. (1932), The Modern Corporation and Private Property, Macmillan, New York.

Bhagat, S and Black, B. (2002), "The non-correlation between board independence and longterm firm performance", Journal of Corporation Law, Vol. 27 No. 2, pp. 231-273.

Bowen, H. (1953), Social responsibilities of the business-man. Harper and Row, New York. 
Campbell, J. L. (2007), "Why would corporations behave in socially responsible ways? An institutional theory of corporate social responsibility", Academy of Management Review, Vol. 32 No. 3, pp. 946-967.

Cheng, S. (2008), "Board size and the variability of corporate performance", Journal of Financial Economics, Vol. 87 No. 1, pp. 157-176.

Chijoke-Mgbame, M. A. and Mgbame, C. O (2018), "Discretionary Environmental Disclosures of Corporations in Nigeria", International Journal of Disclosure and Governance, Vol. 15 No 4, pp. 252-261.

Darko, J., Aribi, Z. A., and Uzonwanne, G. C. (2016), "Corporate governance: The impact of director and board structure, ownership structure and corporate control on the performance of listed companies on the Ghana stock exchange". Corporate Governance: The International Journal of Business in Society, Vol. 16 No. 2, pp. 259-277.

Deegan, C. (2002), "The Legitimising Effect of Social and Environmental Disclosures - A Theoretical Foundation", Accounting, Auditing and Accountability Journal Vol. 15 No 3, pp. $282-311$.

Demsetz, H., and Villalonga, B. (2001), "Ownership structure and corporate performance", Journal of Corporate Finance, Vol. 7 No. 3, pp.209-233.

Dey, A. (2008), "Corporate governance and agency conflicts", Journal of Accounting Research, Vol. 46 No. 5, pp. 1143-1181.

Donaldson, L., and Davis, J. H. (1991), "Stewardship theory or agency theory: CEO governance and Shareholder returns", Australian Journal of Management, Vol 16, pp. 49-64.

Ducassy, I., and Montandrau, S. (2015), "Corporate social performance, ownership structure, and corporate governance in France", Research in International Business and Finance, Vol 34, pp. 383-396.

Duppati, G. R., Scrimgeour, F., and Sune, A. (2019), "Relevance of corporate boards in driving performance in the period that covers financial crisis", Corporate Governance: The International Journal of Business in Society, Vol. 19 No. 2, pp. 321-338.

Duru, A., Iyengar, R. J., and Zampelli, E. M. (2016), "The dynamic relationship between CEO duality and firm performance: The moderating role of board independence", Journal of Business Research, Vol. 69 No. 10, pp. 4269-4277.

Erkens, D. H., Hung, M., and Matos, P. (2012), "Corporate governance in the 2007-2008 financial crisis: Evidence from financial institutions worldwide", Journal of Corporate Finance, Vol. 18 No. 2, pp. 389-411.

Ezzamel, M. and Watson, R., (2002), "Pay comparability across and within UK boards: An empirical analysis of the cash pay awards to CEOs and other board members", Journal of Management Studies, Vol. 39 No. 2, pp.207-232.

Freeman R. E. (1984), Strategic Management: A stakeholder approach. Pitman, Boston. 
García-Ramos, R., and García-Olalla, M. (2011), "Board characteristics and firm performance in public founder-and nonfounder-led family businesses", Journal of Family Business Strategy, Vol. 2 No. 4, pp. 220-231.

Gray, R., Kouhy R. and Lavers, S. (1995), "Corporate Social and Environmental Reporting: A Review of the Literature and A Longitudinal Study of UK Disclosure", Accounting, Auditing and Accountability Journal, Vol. 8 No. 2, pp. 47-77.

Guest, P. (2009), "The impact of board size on firm performance: evidence from the UK", European Journal of Finance, Vol 15 No. 4, pp. 385-404.

Hillman, A. J., and Dalziel, T. (2003), "Boards of directors and firm performance: Integrating agency and resource dependence perspectives", Academy of Management Review, Vol. 28 No. 3, pp. 383-396.

Idowu, S.O. and Papasolomou, I., (2007), "Are the corporate social responsibility matters based on good intentions or false pretences? An empirical study of the motivations behind the issuing of CSR reports by UK companies". Corporate Governance: The International Journal of Business in Society, Vol. 7 No. 2, pp.136-147.

Jamali, D., Safieddine, A. M., and Rabbath, M. (2008), "Corporate governance and corporate social responsibility synergies and interrelationships", Corporate Governance: An International Review, Vol. 16 No. 5, pp. 443-459.

Jensen, M. C., and Meckling, W. H. (1976), "Theory of the firm: Managerial behavior, agency costs and ownership structure", Journal of Financial Economics, Vol. 3 No. 4, pp. 305-360.

Jo, H., and Na, H. (2012), "Does CSR reduce firm risk? Evidence from controversial industry sectors". Journal of Business Ethics, Vol.110 No. 4, pp. 441-456.

Joh, S. W., and Jung, J. Y. (2012), "The effects of outside board on firm value in the emerging market from the perspective of information transaction costs", Asia-Pacific Journal of Financial Studies, Vol. 41 No 2, pp. 175-193.

Keasey, K., and Wright, M. (1997), Corporate governance: responsibilities, risks and remuneration, John Wiley \& Sons Limited, New York.

Kiel, G. C., and Nicholson, G. J. (2003), "Board composition and corporate performance: How the Australian experience informs contrasting theories of corporate governance", Corporate Governance: An International Review, Vol. 11 No. 3, pp. 189-205.

Kim, Y., Park, M. and Wier, B. (2012). Is earnings quality associated with corporate social responsibility? The Accounting Review, Vol. 87 No. 3, pp. 761-796.

Kolk, A., and Pinkse, J. (2010), "The integration of corporate governance in corporate social responsibility disclosures", Corporate Social Responsibility and Environmental Management, Vol. 17 No. 1, pp. 15-26. 
Lasfer, M. A. (2004), "On the monitoring role of the board of directors: The case of the adoption of Cadbury recommendations in the UK", in Corporate Governance (pp. 287-326). Emerald Group Publishing Limited, UK

Landau, S., \& Everitt, B. S. (2004). A handbook of statistical analyses using SPSS, Chapman $\&$ Hall CRC Press LLC, New York.

Lev, B., Petrovits, C. and Radhakrishnan, S. (2010), "Is doing good good for you? How corporate charitable contributions enhance revenue growth". Strategic Management Journal, Vol. 31 No. 2, pp. 182-200.

Liang, Q., Xu, P., and Jiraporn, P. (2013), "Board characteristics and Chinese bank performance", Journal of Banking \& Finance Vol. 37 No. 8, pp. 2953-2968.

Liu, Y., Miletkov, M. K., Wei, Z., and Yang, T. (2015), "Board independence and firm performance in China", Journal of Corporate Finance, 30, pp. 223-244.

Lone, E. J., Chaudhry, A. A., and Khan, I. (2016), "Corporate governance and corporate social responsibility disclosure: Evidence from Pakistan", Corporate Governance: The International Journal of Business in Society, Vol. 16 No. 5, pp. 785-797.

Madueño, J. H., Jorge, M. L., Conesa, I. M., and Martínez-Martínez, D. (2016), "Relationship between corporate social responsibility and competitive performance in Spanish SMEs: Empirical evidence from a stakeholders' perspective”, Business Research Quarterly, Vol. 19 No. 1, pp. 55-72.

Malik, M. S., and Makhdoom, D. D. (2016), "Does Corporate Governance Beget Firm Performance in Fortune Global 500 Companies?", Corporate Governance: The International Journal of Business in Society, Vol. 16 No. 4, pp. 747-764.

McWilliams, A., Siegel, D. S., and Wright, P. M. (2006). Corporate Social Responsibility: International Perspectives. Available at SSRN 900834.

Mishra, S., and Suar, D. (2010), "Does corporate social responsibility influence firm performance of Indian companies?", Journal of Business Ethics, Vol. 95 No. 4, pp. 571-601.

Monks, R., and Minow, N. (2004), Corporate governance, Blackwell Publishing, Malden, MA.

O'Connell, V., and Cramer, N. (2010), “The relationship between firm performance and board characteristics in Ireland”, European Management Journal, Vol. 28 No. 5, pp. 387-399.

Oh, S., Hong, A., and Hwang, J. (2017), “An analysis of CSR on firm financial performance in stakeholder perspectives", Sustainability, Vol. 9 No. 6, pp.1023.

Pearce, J. A., and Zahra, S. A. (1991), "The relative power of CEOs and boards of directors: Associations with corporate performance”. Strategic Management Journal, Vol. 12 No. 2, pp. 135-153.

Pfeffer, J., and Salancik, G. R. (1978), The external control of organizations, Harper and Row, New York 
Qiu, Y., Shaukat, A., and Tharyan, R. (2016), "Environmental and social disclosures: Link with corporate financial performance". The British Accounting Review, Vol. 48 No. 1, pp. 102116.

Saeidi, S. P., Sofian, S., Saeidi, P., Saeidi, S. P., and Saaeidi, S. A. (2015), "How does corporate social responsibility contribute to firm financial performance? The mediating role of competitive advantage, reputation, and customer satisfaction". Journal of Business Research, Vol. 68 No. 2, pp. 341-350.

Saravanamuthu, K. (2004), "What is measured counts: harmonized corporate reporting and sustainable economic development". Critical Perspectives on Accounting, Vol. 15 No. 3, pp. 295-302.

Servaes, H., and Tamayo, A. (2013), "The impact of corporate social responsibility on firm value: The role of customer awareness". Management Science, Vol. 59 No.5, pp.1045-1061.

Sethi, S. P. (1979), "A conceptual framework for environmental analysis of social issues and evaluation of business response patterns". Academy of Management Review, Vol 4 No 1, pp. 63-74.

Singh, M., and Faircloth, S. (2005), "The impact of corporate debt on long term investment and firm performance". Applied Economics, Vol. 37 No. 8, pp. 875-883.

Sundaram, A. K., and Inkpen, A. C. (2004), "The corporate objective revisited". Organization Science, Vol. 15 No. 3, pp.350-363.

Tricker, R. I. (1994), International corporate governance: Text, readings, and cases. Prentice Hall, NJ.

Ujunwa, A. (2012), "Board characteristics and the financial performance of Nigerian quoted firms", Corporate Governance: The International Journal of Business in Society, Vol 12 No.5, pp. 656-674.

Wang, D. H. M., Chen, P. H., Yu, T. H., and Hsiao, C. Y. (2015), "The effects of corporate social responsibility on brand equity and firm performance". Journal of Business Research, Vol. 68 No. 11, pp. 2232-2236.

Wartick, S. L., and Cochran, P. L. (1985), "The evolution of the corporate social performance model". Academy of Management Review, Vol. 10 No. 4, pp. 758-769. 


\section{Tables}

\section{Table 1 Variable Definition}

\begin{tabular}{|c|c|c|}
\hline Variable & Acronym & Definition \\
\hline Return on Asset & ROA & $\begin{array}{l}\text { The ratio of earnings before interest, taxes, depreciation } \\
\text { and amortization divided by total assets }\end{array}$ \\
\hline $\begin{array}{l}\text { Corporate Social } \\
\text { Responsibility Disclosure }\end{array}$ & CSRD & $\begin{array}{l}\text { This is a dummy variable with a value of } 1 \text { if there is a } \\
\text { section in the published annual report dedicated to CSR } \\
\text { activities and } 0 \text { otherwise }\end{array}$ \\
\hline Board Size & BSize & The number of directors on the board \\
\hline Board Independence & BInd & The percentage of independent directors on the board \\
\hline Firm Size & FSize & The log of total assets \\
\hline Firm Age & FAge & $\begin{array}{l}\text { The number of years a company has been listed on the } \\
\text { exchange }\end{array}$ \\
\hline Firm Cash & FCash & $\begin{array}{l}\text { The total of cash and cash equivalents scaled by total } \\
\text { assets }\end{array}$ \\
\hline Leverage & & The ratio of total debts to total assets \\
\hline Ownership & Own & $\begin{array}{l}\text { This is a dummy variable indicating } 1 \text { if more than } 20 \% \\
\text { of the firm is owned by institutional investors and } 0 \\
\text { otherwise }\end{array}$ \\
\hline Big4auditor & B4Aud & $\begin{array}{l}\text { This is a dummy variable with a value of } 1 \text { if the firm is } \\
\text { audited by one of the big four auditors and } 0 \text { otherwise. }\end{array}$ \\
\hline
\end{tabular}

Table 2 Descriptive Statistics

\begin{tabular}{lcccccc}
\hline Variable & Observation & Mean & Std. Dev. & Min & Max & VIF \\
\hline ROA & 816 & 13.290 & 37.841 & -149.687 & 172.053 & \\
CSRD & 810 & 0.44 & 0.50 & 0 & 1 & 1.13 \\
Bsize & 803 & 8.91 & 2.44 & 4 & 19 & 1.37 \\
BInd & 726 & 62.38 & 14.25 & 16.67 & 88.89 & 1.06 \\
FSize & 809 & 6.94 & 0.77 & 4.84 & 9 & 1.59 \\
FAge & 818 & 24.58 & 12.65 & 1 & 56 & 1.08 \\
FCash & 808 & 9.44 & 11.42 & -6.06 & 96.73 & 1.06 \\
Lev & 808 & 76.77 & 140.44 & 4.71 & 1797.72 & 1.06 \\
Own & 811 & 0.19 & 0.39 & 0 & 1 & 1.06 \\
B4Aud & 818 & 0.60 & 0.49 & 0 & 1 & 1.28 \\
\hline
\end{tabular}


Governance and firm performance

\begin{tabular}{|c|c|c|c|c|}
\hline Dependent variable $=$ ROA & $\begin{array}{c}\text { Model } 1 \\
\text { Without } \\
\text { Interaction }\end{array}$ & $\begin{array}{c}\text { Model } 2 \\
\text { With Board } \\
\text { Size } \\
\text { Interaction }\end{array}$ & $\begin{array}{c}\text { Model } 3 \\
\text { With Board } \\
\text { Independence } \\
\text { Interaction }\end{array}$ & $\begin{array}{c}\text { Model } 4 \\
\text { With both } \\
\text { Interaction } \\
\text { Variables }\end{array}$ \\
\hline CSR & $\begin{array}{c}0.236 * * \\
(0.098)\end{array}$ & $\begin{array}{l}0.607^{*} \\
(0.326)\end{array}$ & $\begin{array}{c}0.319 * * * \\
(0.095)\end{array}$ & $\begin{array}{l}0.246^{* *} \\
(0.119)\end{array}$ \\
\hline CSR*BSize & & $\begin{array}{c}0.037 \\
(0.035)\end{array}$ & & $\begin{array}{c}0.034 \\
(0.329)\end{array}$ \\
\hline CSR *BInd & & & $\begin{array}{c}0.014 * * \\
(0.006)\end{array}$ & $\begin{array}{l}0.019^{*} \\
(0.010)\end{array}$ \\
\hline BSize & $\begin{array}{c}0.507 * * \\
(0.201)\end{array}$ & $\begin{array}{l}0.054 * \\
(0.028)\end{array}$ & & $\begin{array}{c}0.056^{* *} \\
(0.028)\end{array}$ \\
\hline BInd & $\begin{array}{l}0.309^{*} \\
(0.176)\end{array}$ & & $\begin{array}{c}0.254 * * \\
(0.103)\end{array}$ & $\begin{array}{c}0.365^{* *} \\
(0.186)\end{array}$ \\
\hline Firm Size & $\begin{array}{l}-0.092 \\
(0.084)\end{array}$ & $\begin{array}{l}-0.087 \\
(0.074)\end{array}$ & $\begin{array}{l}-0.033 \\
(0.067)\end{array}$ & $\begin{array}{l}-0.024 \\
(0.077)\end{array}$ \\
\hline Firm Age & $\begin{array}{l}0.005 \\
(0.004)\end{array}$ & $\begin{array}{l}0.006^{*} \\
(0.004)\end{array}$ & $\begin{array}{l}0.006 \\
(0.004)\end{array}$ & $\begin{array}{c}0.011 \\
(0.007)\end{array}$ \\
\hline Firm Cash & $\begin{array}{c}0.023 * * * \\
(0.004)\end{array}$ & $\begin{array}{c}0.164 * * * \\
(0.031)\end{array}$ & $\begin{array}{c}0.181 * * * \\
(0.031)\end{array}$ & $\begin{array}{c}0.011 * * \\
(0.005)\end{array}$ \\
\hline Leverage & $\begin{array}{c}-0.006^{* * *} \\
(0.002)\end{array}$ & $\begin{array}{c}-0.011 * * * \\
(0.002)\end{array}$ & $\begin{array}{c}-0.012 * * * \\
(0.002)\end{array}$ & $\begin{array}{c}-0.014 * * * \\
(0.003)\end{array}$ \\
\hline Ownership & $\begin{array}{l}-0.002 \\
(0.002)\end{array}$ & $\begin{array}{l}-0.001 \\
(0.002)\end{array}$ & $\begin{array}{l}-0.001 \\
(0.002)\end{array}$ & $\begin{array}{l}-0.006 \\
(0.003)\end{array}$ \\
\hline Big4Auditors & $\begin{array}{c}0.340 * * * \\
(0.113)\end{array}$ & $\begin{array}{c}0.248 * * \\
(0.100)\end{array}$ & $\begin{array}{l}0.198^{*} \\
(0.101)\end{array}$ & $\begin{array}{l}0.291 * * \\
(0.123)\end{array}$ \\
\hline Industry & Yes & Yes & Yes & Yes \\
\hline Year & Yes & Yes & Yes & Yes \\
\hline $\begin{array}{l}\text { Observations } \\
\mathrm{R}^{2}\end{array}$ & $\begin{array}{c}725 \\
0.140\end{array}$ & $\begin{array}{c}725 \\
0.186\end{array}$ & $\begin{array}{c}725 \\
0.201\end{array}$ & $\begin{array}{c}725 \\
0.174\end{array}$ \\
\hline
\end{tabular}

Notes: This table shows the results of the fixed effect regressions. Model 1shows the regression without the governance variable interaction. Model 2 shows the interaction effect with board size. Model 3 shows the interaction effect with board independence. Model 4 includes both interaction variables. Robust standard errors are in parenthesis. $*, * *, * *$, represent significance at $10 \%, 5 \%$ and $1 \%$ respectively. All variables are as defined in Table1. 